\title{
Pentingnya Kepuasan dan Kepercayaan Memediasi Keamanan Bertransaksi Terhadap Minat Beli Konsumen
}

\author{
"The Importance of Satisfaction and Trust Mediate The Security of \\ Transacting Against Consumer Buying Interests"
}

Oleh:

\author{
Anna Wulandari'; Adinewa Surya Prakosa²; Fatimatul Zahroh Anhari; \\ Baskoro Ashar Pamungkas ${ }^{4}$; Rensi Suryanti ${ }^{5}$
}

Program Studi Magister Manajemen 1234; Program Studi Manajemen ${ }^{5}$ Universitas Pelita Bangsa anna.wulandari@pelitabangsa.ac.id; adinewasurya@gmail.com; fatimatulanhari@gmail.com; baskoroashar@gmail.com; Rensi1701@gmail.com

$\begin{array}{llll}\text { Submit: } x x x & \text { Review: } x x x & \text { Accept: } x x x & \text { Publish: } x x x\end{array}$

\begin{abstract}
ABSTRAK
Tujuan penelitian untuk menguji model penelitian yang menyatakan bahwa kepuasan dan kepercayaan memediasi pengaruh keamanan bertransaksi terhadap minat beli konsumen. Metode penelitian ini menggunakan pendekatan kuantitatif, dengan sampel penelitian sebanyak 152 orang konsumen Shopee. Analisis penelitian yang digunakan adalah model struktural diolah software SMART-PLS 3.0. Penelitian menunjukkan kepuasan konsumen tidak memediasi keamanan bertransaksi terhadap minat beli sedangkan kepercayaan konsumen memediasi. Kemanan bertransaksi mempengaruhi kepuasan konsumen dan berdampak pada meningkatnya kepercayaan yang akhirnya mendorong minat beli konsumen.
\end{abstract}

Kata kunci: keamanan; kepuasan; kepercayaan; minat beli

\section{ABSTRACT}

The purpose of the study to test the research model that states that satisfaction and trust mediate the influence of security transactions intercepted consumer buying interests. This research method uses quantitative approach, with a research sample of 152 Shopee consumers. The research analysis used is a structural model processed smart-pls 3.0 software. The results showed that consumer satisfaction does not mediate the security of transacting against buying interests while consumer confidence mediates. Transaction security affects consumer satisfaction and has an impact on increased trust that ultimately drives consumer buying interest.

Keywords: security; satisfaction; trust; buying interest

\section{PENDAHULUAN}

Pandemi Corona Virus Disease 2019 (Covid-19) yang bermula pada bulan Maret 2020 telah menyebabkan beberapa negara menerapkan kebijakan lockdown, yaitu tidak boleh keluar rumah dengan alasan apapun. Bertambahnya jumlah penderita yang terkonformasi terinfeksi virus corona telah menyebabkan pemerintah Indonesia 
menghimbau rakyat Indonesia bekerja, belajar dan dan beribadah di rumah. Pembatasan Sosial Berskala Besar (PSBB) diatur dalam Peraturan Menteri Kesehatan Nomor 9 tahun 2020 dan ditetapkan pada tanggal 3 April 2020 menyatakan bahwa masyarakat melakukan sekolah dan bekerja di rumah, membatasi kegiatan keagamaan, sosial budaya, moda transportasi dan kegiatan lainnya di tempat atau fasilitas umum. Hal ini tidak berlaku untuk kantor atau instansi strategis yang memberikan pelayanan terkait pertahanan dan keamanan, kebutuhan pangan, bahan bakar minyak dan gas, pelayanan kesehatan, perekonomian, keuangan, komunikasi, industri, ekspor impor, distribusi logistik, dan kebutuhan dasar lainnya.

Tahun 2021, Pemerintah Indonesia mengganti istilah PSBB dengan Pemberlakukan Pembatasan Kegiatan Masyarakat (PPKM) yang diatur dalam Instruksi Menteri Dalam Negeri (Inmendagri) Nomor 02 Tahun 2021 tentang Perpanjangan Pemberlakuan Pembatasan Kegiatan Masyarakat untuk Pengendalian Penyebaran Corona Virus Disease 2019, dan ditetapkan pada tanggal 22 Januari 2021. PPKM menyatakan bahwa Pemerintah membatasi tempat/kerja perkantoran dengan menerapkan Work from Home (WFH) 75\% dan Work from Office (WFO) 25\% dengan pemberlakuan protokol kesehatan secara lebih ketat serta kegiatan belajar mengajar dilaksanakan secara daring/online. Kegiatan kuliner (makan/minum di tempat) $25 \%$ dan layanan makanan melalui pesanantar/dibawa pulang $75 \%$ sesuai dengan jam operasional restoran yaitu sampai pukul 20.00 WIB. Kegiatan belajar mengajar dilakukan secara online/daring sedangkan sektor esesnsial dan kebutuhan sehari-hari yang berkaitan dengan kebutuhan pokok masyarakat tetap dapat beroperasi dengan pengaturan jam perasonal, kapasitas, dan penerapan protokol kesehatan secara lebih ketat.

Pembatasan kegiatan menyebabkan masyarakat tidak dapat membeli barang dan jasa secara langsung ke pasar. Masyarakat harus berbelanja online melalui marketplace sebagai perantara antara penjual dan pembeli di dunia maya. Marketplace Indonesia yang populer adalah Tokopedia, Bukalapak, Elevenia, Blanja, BliBli, sedangkan marketplace dari luar negeri yang populer di Indoensia adalah Shopee (Singapura). Lazada (Singapura). JD.ID (Tiongkok), Amazon (Amerika Serikat), Rakuten (Jepang) (Mubarak, 2019). Terdapat 10 marketplace online yang paling banyak dikunjungi perbulan selama April 2021 di asia Tenggara yaitu Shopee $(197,8$ juta kunjungan/bulan), Lazada (161,7 juta kunjungan/bulan), Tokopedia (72,4 juta kunjungan/bulan), Bukalapak (26,8 juta kunjungan/bulan), Tiki (22 juta kunjungan/bulan), BliBli (15,8 juta kunjungan/bulan), Sendo (11,4 juta kunjungan/bulan), Zalora (7,6 juta kunjungan/ bulan), Qoo10 (7 juta kunjungan/bulan), Amazon (3 juta kunjungan/bulan) (Riyanto, 2021).

Perubahan perilaku konsumen terjadi di masa pandemi Covid-19. Dampaknya adalah peningkatan pasar e-commerce di Indoensia. Konsumen yang belum pernah berbelanja online kini dipaksa atau terpaksa mengandalkan platform belanja digital untuk memenuhi kebutuhan selama bekerja, belajar dan beribadah di rumah.

Penetrasi ekonomi digital di Indonesia meningkat yang didominasi pelaku ekonomi yang lahir diatas tahun 1990 dengan jalan aktif mengadaptasi teknologi. Selama tahun 2020, pembelian produk secara online telah mencapai 88 persen dari total pengguna internet $\mathrm{di}$ Indonesia. Pengguna marketplace pada kuartal ke-3 head to head tahun 2020 meningkat dibandingkan tahun 2019.

Q3 tahun 2019, pengunjung Shopee sebesar 55,9 juta orang dan Tokopedia 65,9 juta. Tahun 2020 pengunjung Shopee meningkat tajam hingga 96,5 juta (meningkat sekitar 72\%), dan pengunjung Tokopedia 84,9 juta (meningkat 28\%). Terjadi peningkatan pembelian konsumen melalui e-commerce sebesar $18,1 \%$ atau 
mencapai 98,3 juta transaksi dengan nominal transaksi $\$ 1,4$ juta USD. Realisasi pertumbuhan pasar e-commerce dengan adanya pandemi mencapai $91 \%$ atau jauh melebihi yang diproyeksikan sebelumnya yaitu hanya $54 \%$. Terjadi percepatan pertumbuhan akibat pandemi karena dalam keadaan normal membutuhkan waktu 1,5 hingga 2 tahun. Pandemi Covid19 membawa perubahan dengan pertambahan 12 juta pengguna ecommerce baru dan $40 \%$ diantaranya mengatakan akan terus menggunakan ecommerce walaupun pandemi berakhir (Sirclo, 2020).

Disamping pertumbuhan bisnis ecommerce yang luar biasa, terselip keluhan konsumen atas ketidapuasan mereka terhadap sistem perdagangan elektronik ini. Terdapat aduan mengenai kerugian konsumen yang disebabkan phising dan penyalahgunaan akun salah satunya penyalahgunaan One Time Password (OTP). Phishing yang terjadi berupa seller platform e-commerce mengirimkan tautan yang menyerupai website platform dengan menghubungi nomor telepon pribadi konsumen. Penyalahgunaan akun One Time Password (OTP) berupa manipulasi sehingga pelanggan mengirim OTP sehingga pihak lain dapat melakukan transaksi dengan akun tersebut. Jumlah aduan meningkat pesat, dari 18 pengaduan sepanjang tahun 2019, menjadi 70 pengaduan kerugian bertransaksi di ecommerce mulai Januari hingga Mei 2020. Peranan e-commerce semakin penting, baik pada saat pandemi Covid-19 maupun setelah pandemi Covid-19. Perkembangan commerce ini juga menuntut adanya jaminan keamanan, kenyamanan, dan keselamatan konsumen dalam bertransaksi. Otoritas yang menangani keamanan bertransaksi harus mampu menjamin bahwa tidak ada data pelanggan e-commerce yang bocor. Keamanan bertransaksi juga harus didukung dengan perangkat - perangkat hukum dan regulasi yang menimbulkan rasa aman bagi konsumen untuk melakukan transaksi ecommerce (Komalasari, 2020).
Fenomena di lapangan menunjukkan bahwa pandemi Covid-19 telah menyebabkan perubahan gaya hidup masyarakat yang semakin banyak melakukan belanja online dibandingkan tahun-tahun sebelumnya. Akan tetapi jumlah aduan konsumen yang mengalami kerugian setelah melakukan transaksi online dan adanya ancaman data pelanggan e-commerce yang bocor tentunya dapat menyebabkan konsumen enggan melakukan pembelian secara online. Oleh karena itu, semakin tinggi jaminan keamanan bertransaksi online, maka konsumen akan semakin sering melakukan pembelian secara online melalui marketplace. Hal ini sejalan dengan penelitian yang menyatakan bahwa persepsi keamanan bertransaksi secara online berpengaruh positif terhadap minat beli di e-commerce (Alwafi \& Magnadi, 2016). Akan tetapi, terdapat penelitian yang menyatakan bahwa persepsi keamanan bertransaksi tidak berpengaruh terhadap minat beli di ecommerce (Pratama \& Magnadi, 2017).

Terdapat ketidakkonsistenan hasil penelitian tersebut mendorong dilakukannya penelitian ini untuk mengkonfirmasi kembali pengaruh persepsi keamanan bertransaksi secara online terhadap minat beli konsumen di ecommerce. Penelitian ini menambahkan kepercayaan dan kepuasan konsumen setelah melakukan pembelian online di markerplace. Pemilihan kepercayaan sebagai penghubung pada pengaruh persepsi keamanan bertransaksi terhadap minat beli di e-commerce didasari pada hasil penelitian yang menyatakan bahwa persepsi keamanan berpengaruh terhadap kepercayaan konsumen (Kinasih \& Albari, 2012; Pratama \& Magnadi, 2017). Pemilihan kepuasan konsumen sebagai penghubung pada pengaruh persepsi keamanan bertransaksi terhadap minat beli di e-commerce didasari pada hasil penelitian yang menyatakan bahwa keamanan bertransaksi online berpengaruh terhadap kepuasan konsumen (Kinasih \& Albari, 2012) dan 
kepercayaan berpengaruh terhadap minat beli (Alwafi \& Magnadi, 2016).

Penelitian mengenai e-commerce merupakan bahasan yang menarik, apalagi di masa pandemi Covid-19 ini, belanja online merupakan keharusan di tengah aturan Pemberlakukan Pembatasan Kegiatan Masyarakat (PPKM). Penelitian ini memasukkan dua variabel mediating, yaitu kepuasan dan kepercayaan. Konsumen yang memiliki persepsi bahwa bertransaksi secara online memiliki jaminan keamanan yang tinggi, maka akan menimbulkan kepuasan berbelanja online pada konsumen tersebut, sehingga konsumen akan memiliki persepsi bahwa berbelanja online dapat dipercaya, dan pada akhirnya konsumen akan berminat melakukan pembelian ulang. Oleh karena itu, tujuan penelitian ini adalah untuk menguji pengaruh persepsi keamanan bertransaksi terhadap minat beli berbelanja online, yang dimediasi oleh kepuasan konsumen dan kepercayaan konsumen kepada toko online.

\section{METODE PENELITIAN}

\section{Pengembangan Model}

\section{keamanan bertransaksi dan kepuasan konsumen}

Keamanan bertransaksi merupakan jaminan atas kerahasian data pribadi dan transaksi keuangan yang dilakukan oleh konsumen. Data yang aman adalah data yang sulit diunduh dan dimodifikasi oleh hacker. Penggunaan identitas diri (ID), password, personal identification number (PIN) merupakan bentuk pengamanan yang digunakan untuk melindungi data dan transaksi konsumen (Kinasih \& Albari, 2012). Konsumen yang merasakan adanya keamanan dalam bertransaksi akan merasa puas dengan transaksi yang telah dilakukannya (Kinasih \& Albari, 2012; Sari \& Oswari, 2020; Vasić, Kilibarda, \& Kaurin, 2019).

H1 : Keamanan bertransaksi berpengaruh positif terhadap kepuasan konsumen

\section{Keamanan bertransaksi dan kepercayaan konsumen}

Keamanan bertransaksi berkaitan langsung dengan kepercayaan konsumen online. Konsumen yang merasa aman memberikan informasi pribadi dan dapat melakukan transaksi keuangan secara online, maka konsumen meyakini bahwa perusahaan tidak akan melakukan tindakan tercela, memiliki reputasi yang baik dan dapat diandalkan dalam memenuhi janji dan komitmennya. Jika konsumen memiliki persepsi bahwa transaksi yang dilakukannya aman atau produsen dapat menampilkan nilai yang positif di mata konsumen, maka semakin tinggi kepercayaan yang akan diberikan oleh konsumen kepada produsen (Kinasih \& Albari, 2012)

H2 : Keamanan bertransaksi berpengaruh positif terhadap kepercayaan konsumen

\section{Kepuasan konsumen dan kepercayaan konsumen}

Tampilan pada aplikasi yang telah sesuai dengan harapan konsumen akan menimbulkan rasa percaya bahwa prodisen memiliki reputasi yang baik. Konsumen yang memandang bahwa produsen yang memiliki sumber daya yang dibutuhkan untuk menjalankan aktivitas bisnisnya dan mampu memberikan pelayanan yang lebih baik daripada pelayanan yang diharapkan, maka konsumen akan merasa yakin bahwa produsen mampu memenuhi janji dan komitmennya untuk melayani konsumen dengan baik. Oleh karena itu, jika konsumen merasa puas maka konsumen akan percaya kepada kompetensi, kehandalan dan kejujuran perusahaan (Kinasih \& Albari, 2012; Norhermaya \& Soesanto, 2016; Elrado, Kumadji, \& Yulianto, 2014).

H3 : Kepuasan konsumen berpengaruh positif terhadap kepercayaan konsumen

\section{Kepuasan konsumen dan minat beli}

Konsumen dapat melakukan penilaian terhadap suatu produk yang telah dibelinya. Konsumen yang mendapatkan 
pelayanan lebih dari yang diharapkannya maka akan melakukan pembelian ulang (Dewi, Riani, Harsono, \& Setiawan, 2018; Keni, Aritonang, \& Pamungkas, 2019; Saleem, Ghafar, Ibrahim, Yousuf, \& Ahmed, 2015; Juliana, Noval, Hubner, \& Bernarto, 2020). Pada produsen yang sedang bermasalah atau berkinerja buruk maka konsumen tidak menerima pelayanan sesuai dengan yang dijanjikan sehingga tidak ada minat untuk membeli kembali dari produsen tersebut (Lewin \& Johnston, 2008)

H4 : Kepuasan konsumen berpengaruh positif terhadap minat beli

\section{Kepercayaan konsumen dan minat beli}

Kepercayaan sangat penting dalam transaksi online karena konsumen harus mengirimkan data pribadinya dan melakukan pembayaran secara online. Konsumen hanya akan melakukan transaksi secara online apabila percaya pada reputasi, janji dan komitmen penjual. Apabila penjual dapat dipercaya maka konsumen akan melakukan pembelian ulang, sedangkan apabila penjual tidak dapat diandalkan janji dan komitmennya untuk memberikan pelayanan terbaik, maka konsumen tidak akan melakukan pembelian ulang. Rasa percaya yang terbangun dari konsumen kepada penjual akan mendorong konsumen untuk membeli (Alwafi \& Magnadi, 2016; Pratama \& Magnadi, 2017; Norhermaya \& Soesanto, 2016; Hanafi, 2020)

H5 : Kepercayaan konsumen berpengaruh positif terhadap minat beli

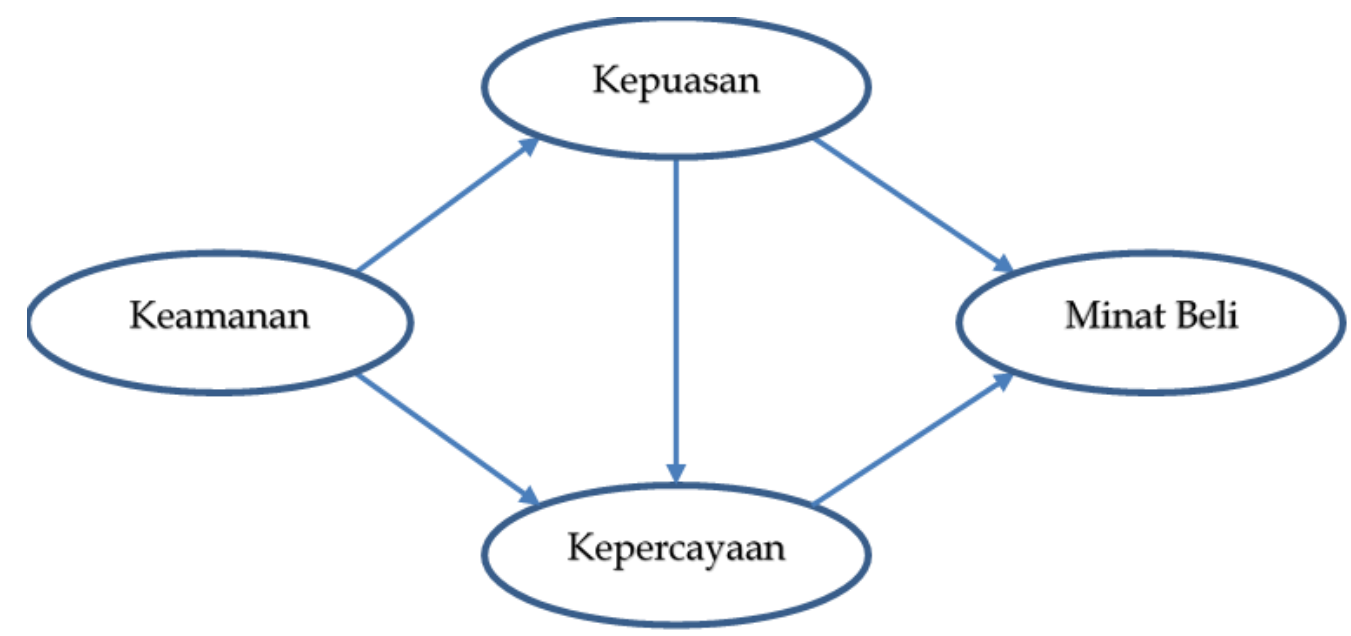

Gambar 1. Model Penelitian

\section{Desain Penelitian}

Transaksi secara online memerlukan jaminan keamanan. Keamanan bertransaksi dapat mempengaruhi kepuasan konsumen sehingga terbangun kepercayaan konsumen kepada penjual dan mendorong konsumen tertarik melakukan pembelian.

\section{Sampling}

Populasi penelitian ini adalah semua orang yang berbelanja di Shopee.com.
Sampel penelitian (Mulyanto \& Wulandari, 2010) adalah 152 orang yang berbelanja di Shopee.com. Teknik pengambilan sampel dilakukan menggunakan googleform untuk mengisi kuesioner secara online.

\section{Operasionalisasi Variabel}

Untuk mengukur variabel keamanan bertransaksi, kepuasan, kepercayaan dan minat beli konsumen, maka digunakan indikator sebagaimana terdapat pada tabel 1. 
Tabel 1. Operasionalisasi Variabel

\begin{tabular}{|c|c|c|}
\hline $\begin{array}{c}\text { Variabel/ } \\
\text { Konsep }\end{array}$ & Indikator & Skala \\
\hline $\begin{array}{l}\text { Keamanan } \\
\text { (Kinasih \& } \\
\text { Albari, } \\
\text { 2012)) }\end{array}$ & $\begin{array}{l}\text { - } \quad \text { Shopee memberikan keamanan online kepada konsumennya } \\
\text { - } \text { Data di Shopee tidak dapat dimodifikasi oleh hacker } \\
\text { - }\end{array}$ & $1-10$ \\
\hline $\begin{array}{l}\text { Kepuasan } \\
\text { (Alwafi \& } \\
\text { Magnadi, } \\
\text { 2016) }\end{array}$ & $\begin{array}{l}\text { - Penampilan aplikasi Shopee sesuai harapan } \\
\text { - Shopee memiliki pengalaman tentang pemasaran online } \\
\text { - } \quad \text { Shopee mengenal penggunanya dengan baik } \\
\text { - Shopee mempunyai sumber daya untuk menjalankan aktivitas } \\
\text { bisnis online }\end{array}$ & $1-10$ \\
\hline $\begin{array}{l}\text { Kepercayaan } \\
\text { (Kinasih \& } \\
\text { Albari, 2012) }\end{array}$ & $\begin{array}{l}\text { - } \quad \text { Shopee handal sebagai platform belanja online } \\
\text { - Shopee memiliki reputasi yang baik dalam jual beli online } \\
\text { - } \text { Shopee menanamkan kepercayaan } \\
\text { - } \quad \text { Shopee memenuhi janji dan komitmennya } \\
\text { - } \quad \text { Shopee tidak bersikap oportunis }\end{array}$ & $1-10$ \\
\hline $\begin{array}{l}\text { Minat Beli } \\
\text { (Alwafi \& } \\
\text { Magnadi, } \\
\text { 2016) }\end{array}$ & $\begin{array}{l}\text { - Saya berminat transaksi di Shopee di masa yang akan datang } \\
\text { - Saya semakin berminat melakukan pembelian di Shopee karena } \\
\text { testimoni teman dan keluarga yang berbelanja di Shopee } \\
\text { - Saran dan opini orang lain menumbuhkan minat pembelian di } \\
\text { Shopee }\end{array}$ & $1-10$ \\
\hline
\end{tabular}

Sumber: Rangkuman teori, 2021

\section{Metode Analisis}

Metode analisis dengan pendekatan kuantitatif yang bertujuan menganalisis pengaruh keamanan bertransaksi terhadap minat beli konsumen yang dimediasi oleh kepuasan dan kepercayaan konsumen kepada penjual. Analisa datanya menggunakan alat analisis dengan metode PLS (partial least square) dimana pengolahannya dilakukan dengan software Smart PLS 3.0. Langkah analisis meliputi pengujian outer dan inner model.
Pengujian outer menggunakan loading outer sebagai bentuk uji validitas dengan cut off $>0,7$ tetapi masih tetap dipertahankan jika nilai loadings outer tidak kurang dari 0,4. Cronbach's Alpha dengan cut off $>0,7$ dan nilai $\rho c$ (composite reliability) dengan cut off $>0,8$ digunakan untuk pengujian Reliabilitas. Pengujian inner model sebagai model structural menggunakan R2 dan Estimasi koefisien. Cut off untuk variabel laten endogenous R2> 0,2. Pengujian hubungan jalur dalam model structural menggunakan standar estimasi dengan cut off p-value $<0,05$. 


\section{HASIL PENELITIAN PEMBAHASAN}

DAN

\section{Hasil}

Resonden penelitian adalah 152 orang konsumen Shopee yang sebagian besar adalah perempuan, dengan usia diatas 25 tahun dan berpendidikan SLTA. Hasil pengujian outer yang digunakan untuk pengujian validitas dan reliabilitas menunjukkan bahwa seluruh indikator pada setiap variabel telah valid karena telah lebih besar daripada 0,7. Seluruh variabel juga telah reliabel karena telah memenuhi cut off yang digunakan dalam penelitian ini (cronbach alpha keamanan 0,894; kepuasan konsumen 0,878; kepercayaan konsumen 0,914 dan minat beli 0,844 lebih besar dari 0,7 sedangkan composite reliability keamanan 0,917; kepuasan konsumen 0,916; kepercayaan konsumen 0,937 dan minat beli 0,905 lebih besar daripada 0,8 ).

Model dapat diterima karena seluruh variabel endogen memiliki nilai $\mathrm{R}$ square lebih besar dari 0,2. Variabel endogen kepercayaan konsumen memiliki nilai $\mathrm{R}$ square 0,836 atau dalam kategori kuat, variabel endogen kepuasan konsumen dengan nilai $\mathrm{R}$ square 0,719 dalam kategori kuat, dan variabel endogen minat beli dengan nilai $R$ square 0,676 dalam kategori substansial.

Estimasi dari indikator ke variabel dan keterkaitan antar variabel. Seluruh indikator telah berkontribusi membentuk masing-masing variabel. Indikator $X 4$ merupakan indikator utama pembentuk keamanan bertransaksi, P4 sebagai indikator utama kepuasan konsumen, K3 sebagai indikator utama kepercayaan konsumen dan Y2 merupakan indikator utama dari minat beli.

Tabel 2. Data Responden

\begin{tabular}{|c|c|c|}
\hline Karakteristik & Jumlah & Persen \\
\hline \multicolumn{3}{|l|}{ Jenis Kelamin } \\
\hline - Perempuan & 55 & 36,2 \\
\hline - Laki-laki & 97 & 63,8 \\
\hline \multicolumn{3}{|l|}{ Usia } \\
\hline - Dibawah 25 tahun & 63 & 41,4 \\
\hline - Diatas 25 tahun & 89 & 58,6 \\
\hline \multicolumn{3}{|l|}{ Pendidikan Terakhir } \\
\hline - $\quad$ SLTA & 62 & 40,8 \\
\hline - Diploma & 21 & 13,8 \\
\hline - Sarjana & 57 & 37,5 \\
\hline - Pascasarjana & 12 & 7,9 \\
\hline
\end{tabular}

Sumber: Data hasil kuesioner yang diolah, 2021 
Tabel 3. Outer Model

\begin{tabular}{|c|c|c|c|c|}
\hline Variabel/Indikator & $\begin{array}{l}\text { Outer } \\
\text { Loading }\end{array}$ & $\begin{array}{l}\text { Cromba } \\
\text { h Alpha }\end{array}$ & $\begin{array}{l}\text { Composite } \\
\text { Reliability }\end{array}$ & Kesimpulan \\
\hline Keamanan & & 0,894 & 0,917 & Reliabel \\
\hline $\begin{array}{l}\text { - Shopee memberikan keamanan online } \\
\text { kepada konsumennya }\end{array}$ & 0,797 & & & Valid \\
\hline $\begin{array}{l}\text { - Data di Shopee tidak dapat dimodifikasi } \\
\text { oleh hacker }\end{array}$ & 0,748 & & & Valid \\
\hline $\begin{array}{l}\text { Pembelian di Shopee tidak menimbulkan } \\
\text { masalah keuangan }\end{array}$ & 0,789 & & & Valid \\
\hline $\begin{array}{l}\text { - Terdapat keamanan membayar elektronik } \\
\text { di Shopee }\end{array}$ & 0,821 & & & Valid \\
\hline $\begin{array}{l}\text { - Terdapat keamanan membagi informasi } \\
\text { pribadi kepada Shopee }\end{array}$ & 0,739 & & & Valid \\
\hline $\begin{array}{l}\text { - Shopee memberikan jaminan atas } \\
\text { informasi data pribadi yang saya berikan }\end{array}$ & 0,815 & & & Valid \\
\hline $\begin{array}{l}\text { - Shopee memiliki mekanisme pengiriman } \\
\text { informasi yang baik }\end{array}$ & 0,760 & & & Valid \\
\hline Kepuasan & & 0,878 & 0,916 & Reliabel \\
\hline $\begin{array}{l}\text { - Penampilan aplikasi Shopee sesuai } \\
\text { harapan }\end{array}$ & 0,814 & & & Valid \\
\hline $\begin{array}{l}\text { - Shopee memiliki pengalaman tentang } \\
\text { pemasaran online }\end{array}$ & 0,857 & & & Valid \\
\hline $\begin{array}{l}\text { - Shopee mengenal penggunanya dengan } \\
\text { baik }\end{array}$ & 0,859 & & & Valid \\
\hline $\begin{array}{l}\text { - Shopee mempunyai sumber daya untuk } \\
\text { menjalankan aktivitas bisnis online }\end{array}$ & 0,891 & & & Valid \\
\hline Kepercayaan & & 0,914 & 0,937 & Reliabel \\
\hline $\begin{array}{l}\text { - Shopee dapat diandalkan untuk berbelanja } \\
\text { online }\end{array}$ & 0,874 & & & Valid \\
\hline $\begin{array}{l}\text { - Shopee memiliki reputasi yang baik dalam } \\
\text { jual beli online }\end{array}$ & 0,910 & & & Valid \\
\hline - Shopee menanamkan kepercayaan & 0,921 & & & Valid \\
\hline - Shopee memenuhi janji dan komitmennya & 0,874 & & & Valid \\
\hline - Shopee tidak bersikap oportunis & 0,735 & & & Valid \\
\hline Minat Beli & & 0,844 & 0,905 & Reliabel \\
\hline $\begin{array}{l}\text { - Saya berniat bertransaksi di Shopee di } \\
\text { masa yang akan datang }\end{array}$ & 0,871 & & & Valid \\
\hline $\begin{array}{l}\text { Saya tertarik melakukan pembelian di } \\
\text { Shopee setelah mendengar testimoni teman } \\
\text { dan keluarga }\end{array}$ & 0,874 & & & Valid \\
\hline $\begin{array}{l}\text { Saran dan opini dari orang lain } \\
\text { menumbuhkan minat saya untuk } \\
\text { melakukan pembelian di Shopee }\end{array}$ & 0,872 & & & Valid \\
\hline
\end{tabular}

Sumber: Hasil Pengolahan, 2021

" "Anna Wulandari; Adinewa Surya Prakosa; Fatimatul Zahro; Baskoro Ashar Pamungkas; Rensi Suryanti:"

8 "Pentingnya Kepuasan dan Kepercayaan Memediasi Keamanan Bertransaksi ..." 
Tabel 4. Indeks Pengujian Model

\begin{tabular}{lllll}
\hline \multicolumn{1}{c}{ Endogenous Variabel } & $\begin{array}{l}\text { Cut of } \\
\text { Value }\end{array}$ & $\begin{array}{c}\text { Hasil } \\
\text { Analisis }\end{array}$ & Evaluasi model \\
\hline $\mathrm{R}^{2}$ & & & & \\
$-\quad$ Kepercayaan & $\geq 0,20$ & 0,834 & Fit \\
$-\quad$ Kepuasan & $\geq 0,20$ & 0,717 & Fit \\
- & Minat Beli & $\geq 0,20$ & 0,672 & Fit \\
\hline
\end{tabular}

Sumber: Data Primer yang diolah, 2021

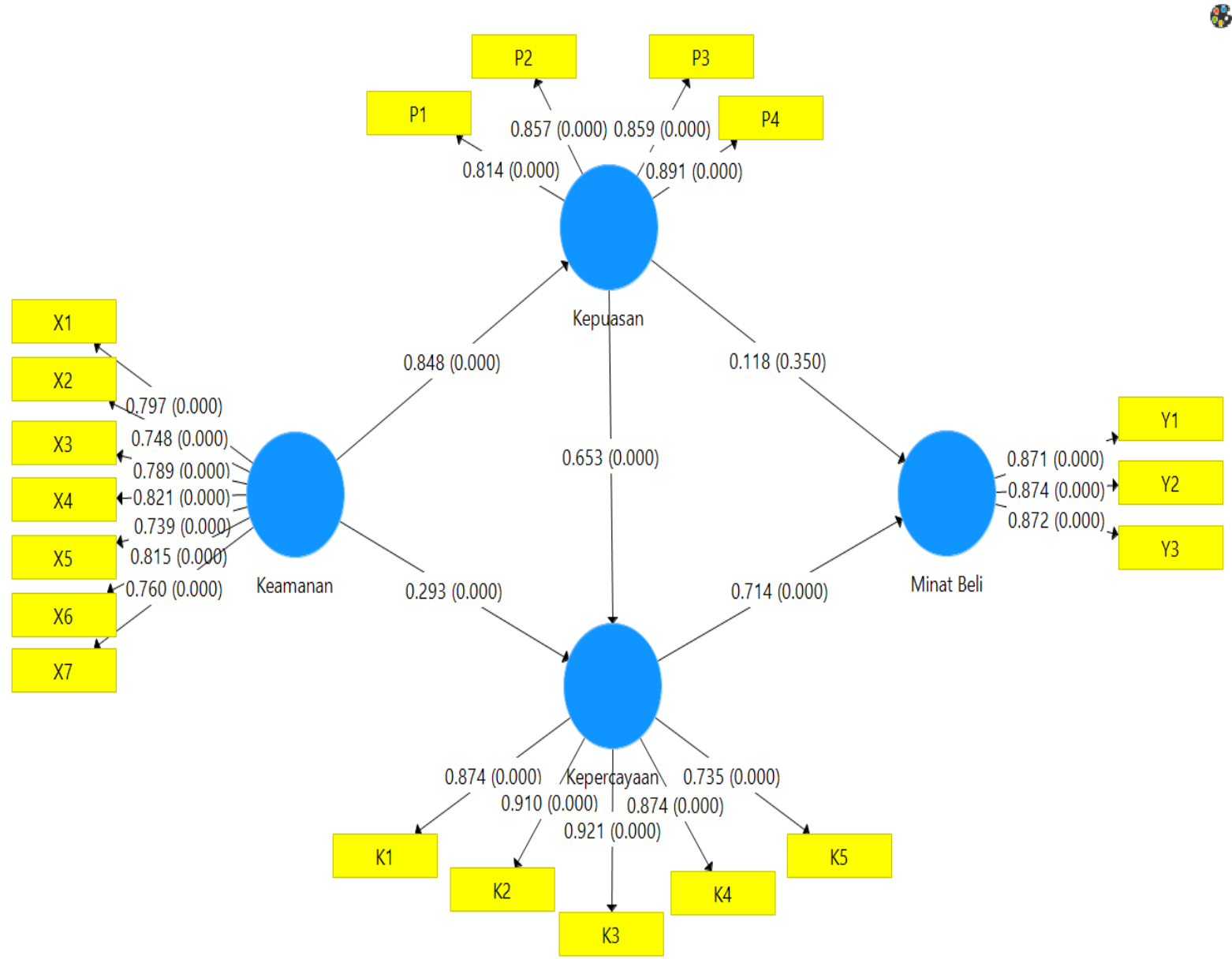

Gambar 2. Full Model

Pengaruh antar variabel dalam model menunjukkan bahwa: 1) keamanan bertransaksi positif signifikan terhadap kepuasan konsumen; 2) keamanan bertransaksi positif signifikan terhadap kepercayaan; 3) kepuasan konsumen positif signifikan terhadap kepercayaan; 4) Kepuasan konsumen tidak signifikan terhadap minat beli; 5) kepercayaan konsumen positif signifikan terhadap minat beli. Informasi lain yang diperoleh adalah: 1) keamanan bertransaksi terhadap minat beli tidak signifikan dimediasi kepuasan; positif signifikan dimediasi kepercayaan; positif signifikan dimediasi kepuasan dan kepercayaan. 
Tabel 5. Estimasi

\begin{tabular}{|c|c|c|c|c|}
\hline Alur & Jenis & $\begin{array}{c}\text { Std. } \\
\text { Estimates }\end{array}$ & P-Value & Kesimpulan \\
\hline Keamanan $\rightarrow$ Kepuasan & Langsung & 0,848 & 0,000 & Signifikan \\
\hline Keamanan $\rightarrow$ Kepercayaan & Langsung & 0,293 & 0,000 & Signifikan \\
\hline Kepuasan $\rightarrow$ Kepercayaan & Langsung & 0,653 & 0,000 & Signifikan \\
\hline Kepuasan $\rightarrow$ Minat Beli & Langsung & 0,118 & 0,350 & $\begin{array}{c}\text { Tidak } \\
\text { Signifikan }\end{array}$ \\
\hline Kepercayaan $\rightarrow$ Minat Beli & Langsung & 0,714 & 0,000 & Signifikan \\
\hline $\begin{array}{l}\text { Keamanan } \rightarrow \text { Kepuasan } \rightarrow \\
\text { Kepercayaan }\end{array}$ & Tidak Langsung & 0,554 & 0,000 & Signifikan \\
\hline $\begin{array}{l}\text { Keamanan } \rightarrow \text { Kepercayaan } \rightarrow \\
\text { Minat Beli }\end{array}$ & Tidak Langsung & 0,209 & 0,003 & Signifikan \\
\hline $\begin{array}{l}\text { Kepuasan } \rightarrow \text { Kepercayaan } \rightarrow \\
\text { Minat Beli }\end{array}$ & Tidak Langsung & 0,466 & 0,000 & Signifikan \\
\hline $\begin{array}{l}\text { Keamanan } \rightarrow \text { Kepuasan } \rightarrow \\
\text { Minat Beli }\end{array}$ & Tidak Langsung & 0,100 & 0,351 & $\begin{array}{c}\text { Tidak } \\
\text { Signifikan }\end{array}$ \\
\hline $\begin{array}{l}\text { Keamanan } \rightarrow \text { Kepuasan } \rightarrow \\
\text { Kepercayaan } \rightarrow \text { Minat Beli }\end{array}$ & Tidak Langsung & 0,395 & 0,000 & Signifikan \\
\hline
\end{tabular}

Sumber: Data penelitian yang diolah, 2021

\section{Pembahasan}

\section{Keamanan bertransaksi terhadap kepuasan konsumen}

Semakin tinggi keamanan bertransaksi dipersepsikan konsumen, semakin tinggi pula kepuasan yang dirasakan. Semakin tinggi kemampuan Shopee memberikan jaminan keamanan transaksi, data, informasi dan pengiriman akan membuat konsumen semakin puas.

Hasil penelitian ini memperkuat penelitian sebelumnya (Kinasih \& Albari, 2012; Sari \& Oswari, 2020; Vasić, Kilibarda, \& Kaurin, 2019) dimana keamanan berpengaruh terhadap kepuasan. Persepsi keamanan yang dimaksud khususnya berkaitan dengan keamanan membayar elektronik di Shopee.
Pengaruh keamanan bertransaksi terhadap kepercayaan konsumen

Semakin tinggi keamanan bertransaksi dipersepsikan konsumen, semakin tinggi pula kepercayaan yang diberikan konsumen pada Shopee. Kemampuan Shopee memberikan jaminan keamanan transaksi, data, informasi dan pengiriman yang semakin baik membuat kepercayaan konsumen meningkat.

Hasil penelitian ini memperkuat temuan sebelumnya (Kinasih \& Albari, 2012) dimana keamanan mempengaruhi kepercayaan. Konsumen yang mendapatkan rasa aman dalam bertransaksi khususnya dalam hal pembayaran secara elektronik lebih percaya kepada aplikasi. 
Pengaruh kepuasan konsumen terhadap kepercayaan konsumen

Semakin tinggi kepuasan konsumen semakin tinggi pula kepercayaan konsumen pada Shopee. Konsumen yang puas dengan tampilan aplikasi, pengalaman bertransaksi, merasa dikenal, dan layanan memiliki kepercayaan yang tinggi.

Hasil penelitian ini memperkuat temuan sebelumnya (Kinasih \& Albari, 2012; Norhermaya \& Soesanto, 2016; Elrado, Kumadji, \& Yulianto, 2014) dimana konsumen kepuasannya tinggi lebih percaya kepada kompetensi, kehandalan dan kejujuran perusahaan. Kepuasan konsumen atas kemampuan sumber daya Shopee untuk menjalankan aktivitas menanamkan kepercayaan konsumen.

\section{Pengaruh kepuasan konsumen terhadap minat beli}

Kepuasan konsumen dalam penelitian ini tidak mempengaruhi minat konsumen dalam hal pembelian. Penampilan, pengalamaan penggunaan dan sumber daya aplikasi yang menjadi ukuran kepuasan tidak menarik minat konsumen melakukan pembelian.

Hasil penelitian ini berbeda dengan temuan sebelumnya (Dewi, Riani, Harsono, \& Setiawan, 2018; Keni, Aritonang, \& Pamungkas, 2019; Saleem, Ghafar, Ibrahim, Yousuf, \& Ahmed, 2015; Juliana, Noval, Hubner, \& Bernarto, 2020), dimana onsumen yang mendapatkan kepuasan akan melakukan pembelian ulang, sebaliknya ketidakpuasan menurunkan minat konsumen (Lewin \& Johnston, 2008). Hal ini dapat terjadi karena tidak semua konsumen yang merasakan kepuasan akan serta merta memiliki ketertarikan untuk membeli.

\section{Pengaruh kepercayaan konsumen terhadap minat beli}

Konsumen dengan kepercayaan yang tinggi memiliki minat yang tinggi pula dalam hal pembelian. Keyakinan bahwa Shoope dapat diandalkan sebagai aplikasi belanja online, memilik reputasi yang baik, memenuhi janji dan memiliki komitmen membuat konsumen lebih tertarik melakukan pembelian.

Hasil penelitian ini memperkuat temuan sebelumnya (Alwafi \& Magnadi, 2016; Pratama \& Magnadi, 2017; Norhermaya \& Soesanto, 2016; Hanafi, 2020) dimana rasa percaya yang terbangun dalam diri konsumen akan mendorong minat pembelian. Kemampuan perusahaan untuk dapat menanamkan kepercayaan di hati konsumen sangat diperlukan agar konsumen lebih berminat untuk melakukan pembelian.

\section{Keamanan Terhadap Kepuasan dan Minat Beli}

Keamanan bertransaksi melalui kepuasan dalam penelitian ini tidak mempengaruhi minat beli. Jaminan keamanan bertransaksi memang telah mampu meningkatkan kepuasan konsumen tetapi belum mampu meningkatkan minat pembelian.

Hasil penelitian ini memperkuat temuan sebelumnya (Pratama \& Magnadi, 2017) dimana keamanan tidak berpengaruh terhadap minat pembelian. Jaminan keamanan khususnya dalam melakukan pembayaran elektronik di Shopee akan mendatangkan kepuasan aktivitas pembelanjaan sebelumnya (Kinasih \& Albari, 2012; Sari \& Oswari, 2020; Vasić, Kilibarda, \& Kaurin, 2019) tetapi tidak mendorong minat konsumen untuk melakukan pembelian di Shopee.

\section{Keamanan Terhadap Kepercayaan dan Minat Beli}

Keamanan bertransaksi melalui kepercayaan dalam penelitian mempengaruhi minat beli. Jaminan keamanan bertransaksi membangkitkan kepercayaan konsumen yang pada akhirnya meningkatkan minat pembelian.

Hasil penelitian ini menjawab permasalahan pada penelitian sebelumnya (Pratama \& Magnadi, 2017) yang hasilnya menunjukkan keamanan tidak mempengaruhi minat beli. Hasil penelitian ini menunjukkan keamanan bertransaksi 
tidak serta merta mendorong minat pembelian konsumen melainkan melalui kepercayaan. Adanya jaminan keamanan pembayaran secara elektronik akan meningkatkan kepercayaan konsumen (Kinasih \& Albari, 2012) yang pada akhirnya meningkatkan minat konsumen (Alwafi \& Magnadi, 2016; Pratama \& Magnadi, 2017; Norhermaya \& Soesanto, 2016; Hanafi, 2020) untuk melakukan pembelian.

\section{Keamanan Terhadap Kepuasan, Kepercayaan dan Minat Beli}

Keamanan bertransaksi dalam penelitian ini mempengaruhi minat beli melalui kepuasan dan kepercayaan. Keamanan bertransaksi yang baik membuat konsumen lebih puas dan konsumen yang merasakan kepuasan menjadi lebih percaya yang pada akhirnya meningkatkan minat pembelian.

Hasil penelitian ini menjawab permasalahan pada penelitian sebelumnya (Pratama \& Magnadi, 2017) yang hasilnya menunjukkan keamanan tidak mempengaruhi minat beli. Hasil penelitian ini menunjukkan keamanan bertransaksi tidak serta merta mendorong minat pembelian konsumen melainkan melalui kepuasan dan kepercayaan. Adanya jaminan keamanan pembayaran secara elektronik akan memberikan kepuasan konsumen (Kinasih \& Albari, 2012; Sari \&
Oswari, 2020; Vasić, Kilibarda, \& Kaurin, 2019). Kepuasan yang dirasakan konsumen meningkatkan kepercayaan konsumen (Kinasih \& Albari, 2012; Norhermaya \& Soesanto, 2016; Elrado, Kumadji, \& Yulianto, 2014) (Kinasih \& Albari, 2012) yang pada akhirnya meningkatkan minat konsumen sebelumnya (Alwafi \& Magnadi, 2016; Pratama \& Magnadi, 2017; Norhermaya \& Soesanto, 2016; Hanafi, 2020) untuk melakukan pembelian.

\section{KESIMPULAN}

Hasil penelitian memberikan jawaban bahwa keamanan bertransaksi mempengaruhi minat beli konsumen secara tidak langsung. Kepuasan konsumen tidak memediasi keamanan bertransaksi terhadap minat beli. Kepercayaan memediasi keamanan bertransaksi terhadap minat beli. Keamanan bertransaksi akan memberikan kepuasan konsumen sehingga konsumen memiliki kepercayaan yang pada akhirnya memunculkan minat untuk membeli.

Penelitian memberikan peluang penelitian lanjutan khususnya berkenaan dengan kepuasan tehadap minat beli. Penelitian bisa dilaukan dengan pengukuran kepuasan yang lebih spesifik atau menambahkan mediasi selain kepercayaan. 


\section{DAFTAR PUSTAKA}

Alwafi, F., \& Magnadi, R. H. (2016). Pengaruh Persepsi Keamanan, Kemudahan Bertransaksi, Kepercayaan Terhadap Toko dan Pengalaman Berbelanja Terhadap Minat Beli Secara Online pada Situs Jual Beli Tokopedia.com. Diponegoro Hournal of Management, 5(2), 115.

Dewi, S. N., Riani, A. L., Harsono, M., \& Setiawan, A. I. (2018). The role of benefit perception and customer satisfaction toward intention to continue moderated purchases experience preference satisfaction (study on Samsung consumers in Solo Raya). International Journal of Engineering \& Technology, 7(4), 5607-5611.

Elrado, M., Kumadji, S., \& Yulianto, E. (2014). Pengaruh Kualitas Pelayanan Terhadap Kepuasan, Kepercayaan dan Loyalitas (Survei pada Pelanggan yang Menginap di Jambuluwuk Batu Resort Kota Batu). Jurnal Administrasi Bisnis (JAB), 15(2).

Hanafi, M. I. (2020). Pengaruh Kepercayaan, Keamanan, Kemudahan dan Risiko Terhadap Minat Beli Via Media Online Butuhbaju.com. PERFORMA: Jurnal Manajemen dan StartUp Bisnis, 4(6), 921-932.

Juliana, Noval, T., Hubner, r. B., \& Bernarto, I. (2020). Ease Of Use Dan Trust Terhadap Purchase Intention Melalui Customer Satisfaction Pada Situs Web Tokopedia. Jurnal Ecodemica, 4(2), 217-229.

Keni, K., Aritonang, L. R., \& Pamungkas, A. S. (2019). Purchase Intention, Satisfaction, Interest, and Previous Purchase Behaviour. International Journal of Innovation, Creativity and Change, 5(6), 1129-1140.

Kinasih, B. S., \& Albari. (2012). Pengaruh Persepsi Keamanan dan Privasi Terhadap Kepuasan dan Kepercayaan Konsumen Online. Jurnal Siasat Bisnis, 16(1), 25-38.

Komalasari, T. D. (2020, 6 11). PikiranRakyat.com. Retrieved from https://www.pikiranrakyat.com/ekonomi/pr-01399518/belanja-online-meningkat-400-persen-bpkn-masihbanyak-dikeluhkan-konsumen

Lewin, J. E., \& Johnston, W. J. (2008). The impact of supplier downsizing on performance, satisfaction over time, and repurchase intentions. Journal of Business $\mathcal{E}$ Industrial Marketing, 23(4), 249-255.

Mulyanto, H., \& Wulandari, A. (2010). Penelitian: Metode \& Analisis. Semarang: CV Agung.

Norhermaya, Y. A., \& Soesanto, H. (2016). Analisis Pengaruh Kepuasan Pelanggan Terhadap Kepercayaan dan Loyalitas Pelanggan untuk Meningkatkan Minat Beli Ulang (Studi pada Online Store Lazada.co.id). Diponegoro Journal of Management, 5(3), 1-13.

Pratama, R. B., \& Magnadi, R. H. (2017). Analisis Pengaruh Promosi dan Persepsi Keamanan Terhadap Kepercayaan Serta Implikasinya Terhadap Minat Beli di E-commerce (Studi pada Pengguna BliBli.com). Diponegoro Journal of Management, 6(3), 1-11.

Riyanto, G. P. $(2021,5$ 10). Kompas.com. Retrieved from https:/ / tekno.kompas.com/read/2021/05/10/15270037/ daftar-10-marketplaceonline-paling-ramai-pengunjung-di-asia-tenggara?page $=$ all

Saleem, A., Ghafar, A., Ibrahim, M., Yousuf, M., \& Ahmed, N. (2015). Product Perceived Quality and Purchase Intention with Consumer Satisfaction. Global Journal of Management and Business Research: E-Marting, 15(1). 
Sari, N. E., \& Oswari, T. (2020). Pengaruh Kemudahan, Kepercayaan dan Keamanan Terhadap Kepuasan Pelanggan Melalui Keputusan Pembelian pada Toko Online Tokopedia. Creative Research Management Journal, 3(2), 34-46.

Sirclo. (2020, 12 10). Sirlco.com. Retrieved from https:/ /www.sirclo.com/jumlah-pengguna-ecommerce-indonesia-di-tahun-2020-meningkat-pesat/

Vasić, N., Kilibarda, M., \& Kaurin, T. (2019). The Influence of Online Shopping Determinants on Customer Satisfaction in the Serbian Market. Journal of Theoretical and Applied Electronis Commerce Research, 14(2), 70-89. doi:10.4067/S0718-18762019000200107 